\title{
Peningkatan Persepsi Guru IPA Terhadap Penggunaan Pendekatan Gamification pada Kegiatan dan Evaluasi Pembelajaran
}

\section{Daniar Setyo Rini $^{{ }^{*}}$, Ade Suryanda ${ }^{1}$ dan Eka Putri Azrai ${ }^{1}$}

${ }^{1}$ Pendidikan Biologi, Universitas Negeri Jakarta, Gd. Hasyim As'jarie, Rawamangun Muka Raya, Pulo Gadung, Jakarta Timur, Indonesia, 13220.

*Email koresponden: daniarsetyorini@unj.ac.id

\author{
ARTICLE INFO \\ Article history \\ Received: 01 Des 2020 \\ Accepted: 03 Apr 2021 \\ Published: 23 Apr 2021

\section{Kata kunci: \\ Gamification; \\ Persepsi Guru IPA;} \\ Pembelajaran Digital
}

\begin{abstract}
A B S T R A K
Background: Pendekatan Gamification diduga dapat memberikan lingkungan belajar yang lebih menyenangkan, membuat siswa lebih berperan aktif, dan merangsang siswa untuk mengorganisasikan pengetahuan yang telah didapat menjadi satu kesatuan yang utuh sehingga terasa menjadi lebih bermakna. Penggunaan Gamification dalam pembelajaran masih jarang digunakan karena guru masih belum banyak mengetahui tentang pendekatan ini sehingga persepsi guru mengenai Gamification masih tergolong rendah Metode: Metode yang digunakan dalam kegiatan ini adalah metode survey disertai dengan metode pembelajaran pengalaman (experiential learning). Hasil: Berdasarkan data yang didapatkan dari hasil pre-test dan post-test, persepsi guru mengenai penggunaan Gamification mengalami perubahan menjadi lebih positif setelah mendapatkan pemaparan mengenai Gamification di kegiatan webinar. Dari total responden 94 orang, terdapat 10 orang responden yang persepsinya mengalami perubahan menjadi lebih positif. Berdasarkan hasil uji t-berpasangan diperoleh hasil bahwa hasil pre-test dan post-test berbeda nyata dengan nilai signifikansi 0,037. Kesimpulan: terjadi perubahan persepsi guru mengenai penggunaan Gamification setelah mengikuti kegiatan webinar.
\end{abstract}

\section{A B S T R A C T}

Background: The gamification approach is thought to provide a more enjoyable learning environment, make students play a more active role, and stimulate students to organize the knowledge they have acquired into a complete unit so that it feels more meaningful. The use of gamification in learning is still rarely used because teachers still don't know much about this approach so that the teacher's perception of gamification is still low. Methods: The method used in this activity is a survey method accompanied by experiential learning methods. Results: Based on the data obtained from the results of the pre-test and posttest, the teacher's perceptions about the use of gamification changed to be more positive after receiving exposure to gamification in the webinar activity. From a total of 94 respondents, there were 10 respondents whose perceptions had changed to be more positive. Based on the results of the paired t-test, it was found that the pre-test and posttest results were significantly different with a significance value of 0.037 . Conclusion: There was a change in teacher perceptions regarding the use of gamification after participating in the webinar.
Digital Learning

Gamification;

Perception;

\section{PENDAHULUAN}

Masuknya era digital membuat perkembangan teknologi berjalan lebih cepat. Perkembangan teknologi diiringi dengan perkembangan metode pembelajaran yang memberikan sebuah peluang dan kesempatan baru bagi dunia pendidikan. Akan tetapi, hal tersebut juga 
memberikan tantangan yang begitu besar bagi guru pada khususnya. Perkembangan zaman membuat tuntutan kompetensi guru juga mengalami perubahan. Guru dituntut untuk berpartisipasi aktif dalam memngembangkan ilmu pengetahuan dan keterampilannya mengenai pembelajaran di era digital.

Implementasi pembelajaran dengan penggunaan teknologi di era digital saat ini nyatanya masih sangat kurang dilakukan oleh sebagian besar guru. Hal ini disebabkan karena persepsi guru akan pembelajaran digital belum terlalu baik. Berdasarkan penelitian yang telah dilakukan oleh Antonio menyebutkan bahwa guru akan dihadapkan pada beberapa pertimbangan pada saat akan mengimplementasikan metode baru dalam kegiatan pembelajarannya seperti outcomes yang diharapkan, ketatalaksanaan kegiatan, biaya dan keuntungan-keuntungan lainnya yang dapat didapatkan dengan penerapan metode baru tersebut (Sánchez-Mena \& Martí-Parreño, 2017). Selain dari alasan diatas banyak juga dari guru-guru yang merasa tidak bias menggunakan teknologi (gagap teknologi) sehingga mereka cenderung takut untuk mencoba dan tidak mudah beradaptasi dengan perubahan.

Permasalahan pemerataan pengetahuan bagi guru menjadi satu hal penting untuk meminimalisasi kurangnya partisipasi guru dalam menerapkan metode pembelajaran berbasis teknologi. Antoni mengatakan bahwa ada empat hal yang menjadi pendorong utama seorang guru ingin menggunakan teknologi dalam proses pembelajarannya yakni attention-motivation, entertainment, interactivity, dan easiness to learn. Empat hal lain yang menjadi faktor penghalang bagi guru yakni lack of resource, students' apathy, subject fit, dan classroom dynamics (Sánchez-Mena \& Martí-Parreño, 2017). Berdasarkan hasil penelitian tersebut terlihat bahwa persepsi seorang guru terhadap suatu hal baru yang akan diimplementasikan dalam proses pembelajarannya menjadi sangat penting. Sehingga pengenalan mengenai kebermanfaatan dan kemudahan pembelajaran berbasis teknologi kepada guru diharapkan mampu meningkatkan persepsi positif guru terhadap pembelajaran berbasis teknologi.

Pendekatan pembelajaran berbasis teknologi yakni Gamification didefinisikan sebagai "the use of game design elements in non-game context" (Deterding et al., 2011). Gamification secara sederhana diartikan sebagai metode pembelajaran yang penyampainnya materi pembelajarannya dikemas dalam bentuk permainan. Konsep utama Gamification adalah tidak dibutuhkan "game" apapun, melainkan guru membuat kelasnya tersebut sebagai games itu sendiri (Hanus \& Fox, 2015). Gamification adalah pendekatan pembelajaran yang dapat dilakukan di kegiatan pembelajaran ataupun proses evaluasi. Secara umum, Gamification banyak dilakukan dengan menggunakan aplikasi games atau permainan online. Walaupun secara konsep Gamification tidak mengharuskan penggunaan game tertentu, akan tetapi penggunaan game tersebut dapat meningkatkan motivasi dan persepsi murid terhadap proses pembelajaran. Gabriel dalam penelitiannya menyatakan bahwa pendekatan Gamification dapat meningkatkan perhatian siswa mengenai materi pembelajaran, serta partisipasi dan proaktif siswa dalam pembelajaran online. Hal ini membuat hasil belajar mereka menjadi lebih baik (Barata et al., 2013).

Adanya pandemi Covid-19 yang sedang melanda di seluruh dunia menyebabkan pelaksanaan kegiatan pembelajaran harus dilakukan melalui sistem daring (secara online). Perkembangan sistem pembelajaran dan aplikasi online yang dapat digunakan pada pembelajaran jarak jauh (daring) terus mengalami perkembangan. Salah satu pendekatan pembelajaran online yang saat ini tengah banyak dilakukan adalah pendekatan Gamification. Gamification adalah pendekatan pembelajaran baik dalam kegiatan pembelajaran ataupun proses evaluasi yang dilakukan dengan menggunakan aplikasi games atau permainan online.

Pendekatan Gamification diduga dapat memberikan lingkungan belajar yang lebih menyenangkan, membuat siswa lebih berperan aktif, dan merangsang siswa untuk mengorganisasikan pengetahuan yang telah didapat menjadi satu kesatuan yang utuh sehingga 
terasa menjadi lebih bermakna. Gamification tengah banyak dilakukan oleh guru-guru baik dari jenjang sekolah dasar sampai dengan sekolah menengah. Akan tetapi, masih banyak pula guruguru yang belum menggunakan pendekatan pembelajaran ini terlebih dalam sistem pembelajaran daring. Sehingga perlu adanya pemberian informasi secara menyeluruh mengenai pendekatan Gamification sebagai salah satu solusi yang ditawarkan untuk memberikan pembelajaran daring yang efektif, efisien dan juga menyenangkan.

Pemberian pengetahuan secara menyeluruh juga diharapkan dapat meningkatkan persepsi guru mengenai penggunaan Gamification sebagai alat evaluasi pembelajaran berbasis teknologi online yang kemudian diharapkan dapat memotivasi guru untuk melakukan pengembangan secara mandiri mengenai proses pembelajaran daring di masa pandemi Covid-19 saat ini.

\section{MASALAH}

Berdasarkan hasil identifikasi yang dilakukan permasalahan yang dihadapi meliputi.

1. Pandemi COVID19 yang terjadi membuat guru harus beradaptasi secara cepat dalam memberikan pembelajaran sistem daring kepada siswa.

2. Terbatasnya waktu yang tersedia untuk mempersiapkan bahan dan metode pembelajaran sistem daring (online).

3. Pembelajaran sistem daring yang terkadang membosankan dan kurang menyenangkan bagi siswa sekolah dasar.

4. Metode pembelajaran sistem daring yang sangat membutuhkan peran aktif siswa dalam mencari pengetahuannya secara mandiri di rumah selama masa pandemi.

5. Mata pelajaran IPA yang memiliki banyak sumber daya alam yang bisa dimanfaatkan secara sederhana di rumah.

6. Tuntutan pembelajar yang makin komplek

7. Keterbatasan pemahaman guru dalam penggunaan teknologi dalam kegiatan pembelajaran

8. Persepsi guru terhadap penggunaan teknologi dalam proses pembelajaran

9. Menjada kestabilan motivasi guru untuk melakukan proses pembelajaran berbasis teknologi internet

10. Guru belum terbiasa dan terlatih untuk mengembangkan metode pembelajaran atau evaluasi dengan menggunakan teknologi.

Mengacu ke permasalahan yang teridentifikasi dilakukan penjajakan awal ke mitra. Dan dari hasil penjajakan disepakati suatu kegiatan yang terfokus pada masalah peningkatan keterampilan guru dalam mengembangkan evaluasi dengan pendekatan Gamification dalam rangka pemenuhan tuntutan proses pembelajaran daring di era digital dan dalam masa pandemi.

\section{METODE PELAKSANAAN}

Metode yang digunakan dalam kegiatan ini adalah metode survey disertai metode pembelajaran pengalaman (experiential learning). Metode ini merupakan suatu proses refleksi pengalaman yang dapat menimbulkan gagasan atau pengetahuan baru. Dalam hal ini guru-guru yang mengikuti kegiatan diajak berdiskusi untuk menggali pengalamannnya selama ini dalam mengelola pembelajaran, mengungkap permasalahan serta ide-ide mereka dalam mengatasi persmasalahan tersebut. Pemberian informasi dari narasumber akan ikut menambah wawasan peserta. Dari proses ini peserta kegiatan akan membentuk konsep-konsep abstrak yang kemudian dicobakan pada berbagai situasi baru. Mencoba menerapkan pada situasi baru suatu konsep abstrak yang telah dibentuk, memberikan suatu pengalaman baru lagi bagi individu, demikian seterusnya proses pembelajaran berlangsung, seperti sebuah siklus (Achmat, 2005). Narasumber memiliki peran yang cukup penting dalam metode ini karena harus dapat memberikan situasi proses belajar yang memfasilitasi peserta dalam memperoleh informasi sebanyak-banyaknya. 
Sehingga, peserta pelatihan memperoleh pengalaman baru atau terbantu menata pengalamannya di masa lampau dengan cara baru (Greenway, 2005).

Program pelatihan ini lebih banyak melibatkan aktifitas peserta melalui diskusi, tanyajawab, brainstorming, observasi, bermain peran (role-play). Pelibatan peserta secara aktif ditujukan supaya peseta tidak bosan dan tidak merasa digurui (Fowlie, 2000). Adapun Langkahlangkah dalam kegiatan ini dibedakan atas: Observasi awal, pemberian informasi dan pendampingan, pendampingan dan pengembangan, monitoring pada saat implementasi atau penggunaan pendekatan Gamification, dan evaluasi kegiatan.

Pengumpulan data telah dilakukan dengan menggunakan metode pre-test dan post-test. Sebelum mendapatkan pemaparan, para guru (peserta) diberikan pre-test berupa kuesioner mengenai persepsi penggunaan pendekatan Gamification dalam pembelajaran. Kuesioner yang dipakai diadaptasi dari kuesioner persepsi guru terhadap penggunaan Gamification oleh Daniah Alabbasi, Lindita Skenderi dan Fauzi Skenderi serta Kuesioner adaptasi teknologi (Alabbasi, 2017; Mundy et al., 2012). Kuesioner terdiri dari 20 butir pernyataan dengan pilihan jawaban menggunakan skala likert 1-5 (sangat tidak setuju - sangat setuju). Data yang telah didapat dianalisis secara deskriptif dan diuji statistik menggunakan uji-t berpasangan untuk mengetahui ada atau tidaknya perbedaan antara hasil pre-test dan post-test.

\section{HASIL DAN PEMBAHASAN}

Kegiatan pengabdian kepada masyarakat (PKM) ini pada awalnya direncanakan untuk dilaksanakan bersama dengan guru-guru dari MGMP wilayah Hambalang, Kabupaten Bogor, Jawa Barat. Akan tetapi, karena terjadinya pandemi Covid-19, menyebabkan kegiatan tidak dapat dilaksanakan sesuai dengan rencana awal dan mengalami perubahan lokasi yakni dilaksanakan bersama dengan guru-guru Sekolah Dasar YPI Al-Azhar Indonesia dengan menggunakan metode webinar online.

Kegiatan webinar dilakukan dalam tim besar oleh beberapa orang dosen yang memiliki keselarasan tema dalam kegiatan pengabdian di tahun 2020. Adapun tema besar yang diangkat oleh webinar pengabdian kali ini adalah "Pembelajaran di Masa Pandemi". Kegiatan webinar terbagi menjadi dua seri dan telah dilaksanakan pada tanggal 15 dan 22 November 2020. Webinar dilakukan dengan menggunakan platform zoom meeting berkapasitas 100 orang. Oleh karena jumlah peserta melebihi kapasitas maka webinar juga disiarkan menggunakan fitur live streaming di youtube.

Seri pertama webinar dilaksanakan pada 15 November 2021 yang dihadiri oleh 168 orang peserta dengan paparan materi mengenai Blended learning berbasis Google classroom dan materi mengenai persiapan siswa dalam menghadapi kompetisi sains nasional. Webinar seri kedua dilaksanakan pada 22 November 2020 yang dihadiri oleh 152 orang peserta dengan pemaparan sumber belajar berbasis teknologi, pemberdayaan keterampilan mengembangkan soal HOTS dan Pendekatan Gamification dalam proses dan evaluasi pada Pembelajaran IPA.

Kegiatan pada kedua seri webinar dimulai dengan pembukaan dan pemaparan materi seperti yang telah disebutkan di paragraf sebelumnya yang kemudian dilanjutkan dengan sesi tanya jawab. Masing-masing kegiatan di setiap seri berlangsung selama kurang lebih 3 jam, dimulai pukul 13.00 WIB dan selesai pada pukul 15.30 WIB sesuai dengan jadwal yang telah direncanakan. Sepanjang kegiatan antusias peserta terlihat sangat baik, hal ini dapat dilihat dari banyaknya pertanyaan yang masuk selama kegiatan tanya jawab dan jumlah peserta yang berada di range 93-98 orang pada zoom meeting sampai dengan acara selesai dilaksanakan.

Secara keseluruhan, pelaksanaan kegiatan berlangsung lancar dan mendapat antusias yang sangat baik dari peserta. Hal ini ditandai dengan jumlah pendaftar yang mencapai \pm 300 orang yang tidak hanya berasal dari guru-guru IPA SDI AL Azhar saja melainkan juga guru-guru 
IPA dan Biologi se-Indonesia. Berdasarkan jumlah peserta yang menghadiri kegiatan dapat dikatakan bahwa kegiatan telah mencapai target peserta yang diharapkan. Adapun detil demografi data peserta yang dijadikan responden dalam kegiatan webinar mengenai pendekatan Gamification tersebut dapat dilihat dalam tabel berikut,

Tabel 1. Demografi Data Peserta Webinar

\begin{tabular}{llll}
\hline & & Frekuensi & Persentase \\
\hline Jenis Kelamin & Laki-laki & 33 & 21,7 \\
Usia & Perempuan & 119 & 78,3 \\
& 19-24 tahun & 8 & 5,3 \\
& 25-30 tahun & 26 & 17,1 \\
& 31-40 tahun & 92 & 60,5 \\
& 41-50 tahun & 21 & 13,8 \\
Pendidikan & $>50$ tahun & 5 & 3,3 \\
terakhir & SMA & 7 & 4,6 \\
\multirow{3}{*}{ Pekerjaan } & S1 & 131 & 86,2 \\
& S2 & 12 & 9,2 \\
& Guru SD & 103 & 67,8 \\
Masa Kerja & Guru SMP & 5 & 3,3 \\
& Guru SMA & 37 & 24,3 \\
& Lainnya & 7 & 4,6 \\
& 0-2 tahun & 7 & 4,6 \\
& 3-5 tahun & 19 & 12,5 \\
& 6-10 tahun & 49 & 32,2 \\
Total peserta & 11-15 tahun & 57 & 37,5 \\
& 16-20 tahun & 14 & 9,2 \\
& $>25$ tahun & 6 & 3,9 \\
\hline
\end{tabular}

Pelaksanaan kegiatan pengabdian masyarakat tahun 2020 telah dilaksanakan dengan baik, namun memiliki beberapa hambatan. Kendala yang dihadapi diantaranya, koneksi internet yang tidak stabil saat pelaksanaan webinar online, pertanyaan yang diajukan selama sesi tanya jawab begitu banyak dan tidak bisa diakomodasi secara maksimal karena keterbatasan waktu, kegiatan pendampingan dan pelatihan yang awalnya direncanakan secara offline tidak bisa terlaksana karena terjadinya pandemi covid-19. Adapun tujuan dari kegiatan pengabdian ini dilakukan untuk membagi pengetahuan kepada guru, juga untuk mengetahui persepsi guru mengenai penggunaan teknologi Gamification dalam proses pembelajaran. Pelaksanaan pengabdian ini juga diharapkan dapat sedikit merubah persepsi guru mengenai pendekatan Gamification kearah positif sehingga dapat dijadikan sebagai salah satu alternatif desain pembelajaran yang menyenangkan di era digital.

Pengumpulan data dilakukan menggunakan teknik pre-test dan post-test. Peserta yang berjumlah 152 orang diberikan pre-test mengenai persepsi dan pengetahuan mereka mengenai pendekatan gamification kemudian peserta diberikan materi mengenai pendekatan gamification dan diakhir kegiatan peserta diberikan posttest. Dari total peserta 152 orang diperoleh data pre-test dan posttest yang lengkap dari 94 orang peserta. Data dari 94 orang peserta inilah yang kemudian dijadikan sampel untuk menganalis peningkatan persepsi guru mengenai pendekatan gamification pada pembelajaran IPA.

Berdasarkan data yang terkumpul diperoleh hasil bahwa persepsi guru mengenai penggunaan pendekatan Gamification dalam proses pembelajaran baik untuk proses kegiatan ataupun evaluasi kegiatan sudah cukup baik. Terlihat dari respon yang diberikan terhadap pertanyaan kuesioner bahwa hampir Sebagian besar setuju dan sangat setuju mengenai 
penggunaan Gamification dalam pembelajaran. Hasil post-testnya pun menunjukkan adanya perubahan jawaban terhadap pernyataan di dalam kuesioner yang lebih menunjuk ke penguatan bahwa peserta dalam hal ini guru memiliki keyakinan dan persepsi yang baik untuk menggunakan pendekatan Gamification dalam proses pembelajaran. Hal ini berarti, sharing pengetahuan yang telah dilakukan melalui kegiatan webinar setidaknya memberikan perubahan yang baik akan persepsi guru mengenai penggunaan pendekatan Gamification.

Pada butir negative yakni butir pernyataan nomor 2-6 dari urutan atas (berdasarkan gambar) Sebagian besar menjawab sangat tidak setuju dan tidak setuju. Butir-butir pernyataan negative tersebut berisi penyataan mengenai penggunaan games dalam proses pembelajaran membuat siswa menjadi lelah, menurunkan motivasi siswa, memberikan dampak negative dan membuat hubungan siswa dengan guru menjadi buruk di dalam kelas. Respon peserta terhadap penyataan tersebut secara keseluruhan sepakat untuk sangat tidak setuju dan tidak setuju. Respon peserta terhadap pernyataan kuesioner mengalami perubahan setelah peserta mendapatkan materi mengenai Gamification. Adapun perbedaan dan perubahan yang terjadi dari persepsi guru terhadap Gamification dapat dilihat dalam gambar berikut,

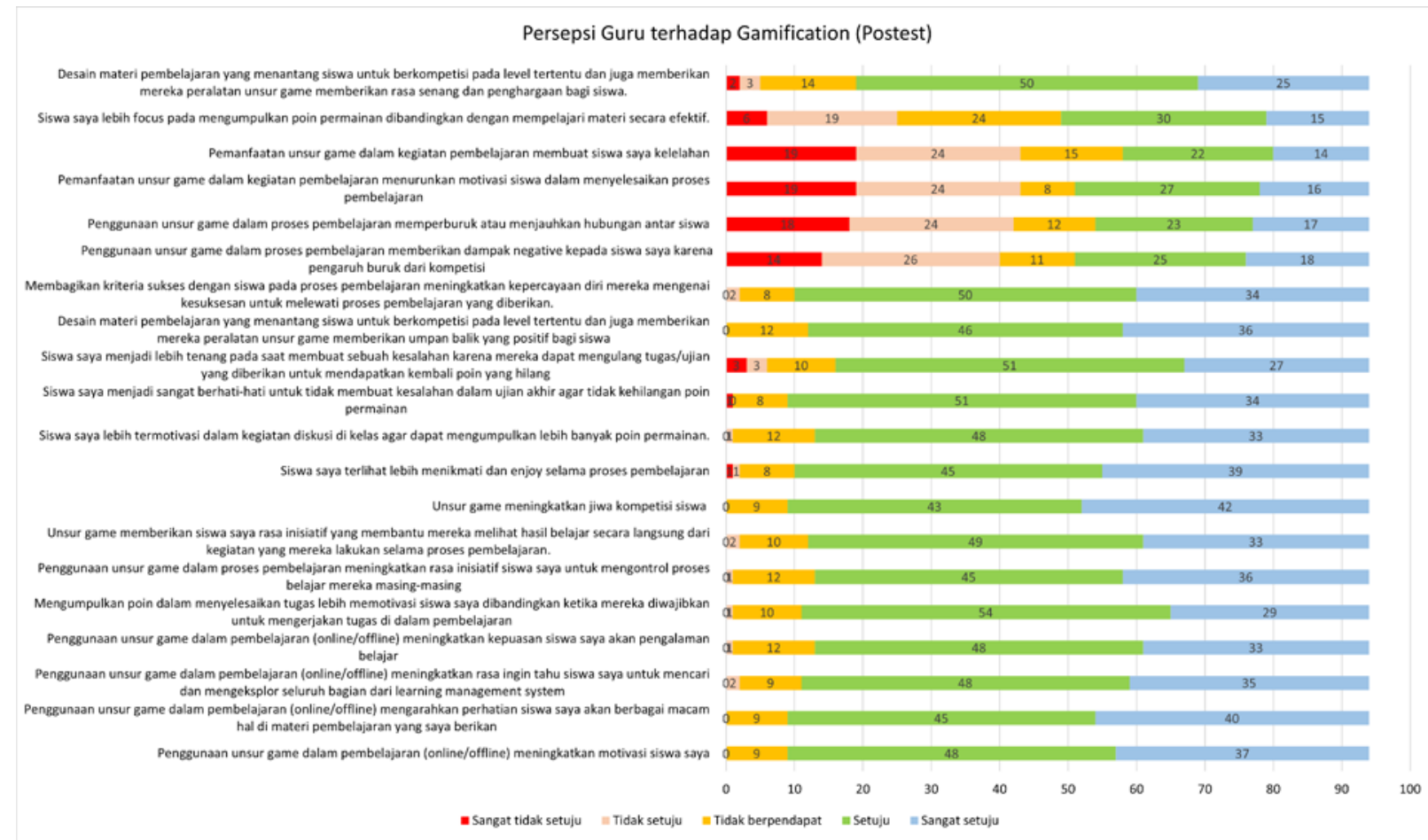

Gambar 1. Persepsi Guru terhadap Penggunaan Pendekatan Gamification dalam Pembelajaran

(Posttest)

Berdasarkan gambar grafik diatas terlihat adanya perubahan skor rata-rata di masingmasing pernyataan. Persepsi guru mengenai penggunaan Gamification mengalami peningkatan yang terlihat dari skor post-test yang diberikan. Pada butir pernyataan positif (butir 1-14) skor post-test mengalami peningkatan dibandingkan skor pre-test. Sedangkan pada butir pernyataan negatif (15-19) skor pada post-test mengalami penurunan dibandingkan pre-test. Hal ini memperlihatkan bahwa persepsi guru terhadap penggunaan Gamification ini berubah menjadi lebih baik atau positif setelah mendapatkan pemaparan mengenai penggunaan pendekatan Gamification melalui kegiatan webinar. Adapun peningkatan skor secara keseluruhan dapat dilihat dalam gambar 4. 
Pada pre-test diperoleh 6 orang guru yang memiliki persepsi rendah terhadap penggunaan Gamification, 71 orang persepsi sedang dan 17 orang berpersepsi tinggi. Hasil posttest menunjukkan terjadinya pengurangan guru dengan persepsi rendah, dari 6 orang berkurang menjadi tinggal 1 orang serta terjadi penambahan pada kriteria persepsi sedang dan tinggi. Hal ini memperlihatkan bahwa sharing materi yang diberikan selama kurang lebih 5 JP dapat mengubah persepsi 10 orang peserta dari total 94 peserta. Sepuluh orang tersebut berubah persepsinya menjadi lebih baik akan penggunaan Gamification dalam proses pembelajaran.

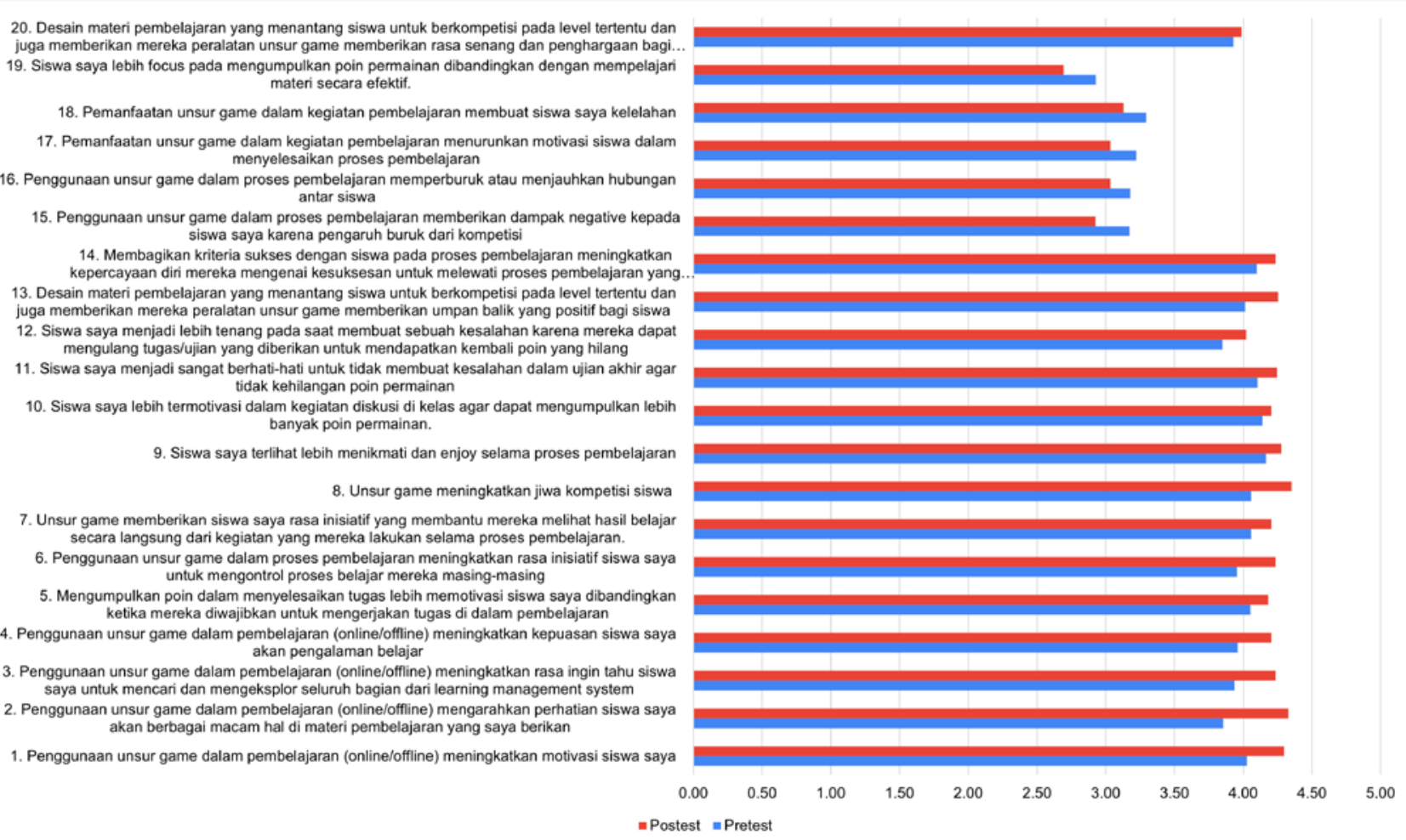

Gambar 2. Perbandingan Skor Rata-rata Persepsi Guru Terhadap Pendekatan Gamification dalam Pembelajaran

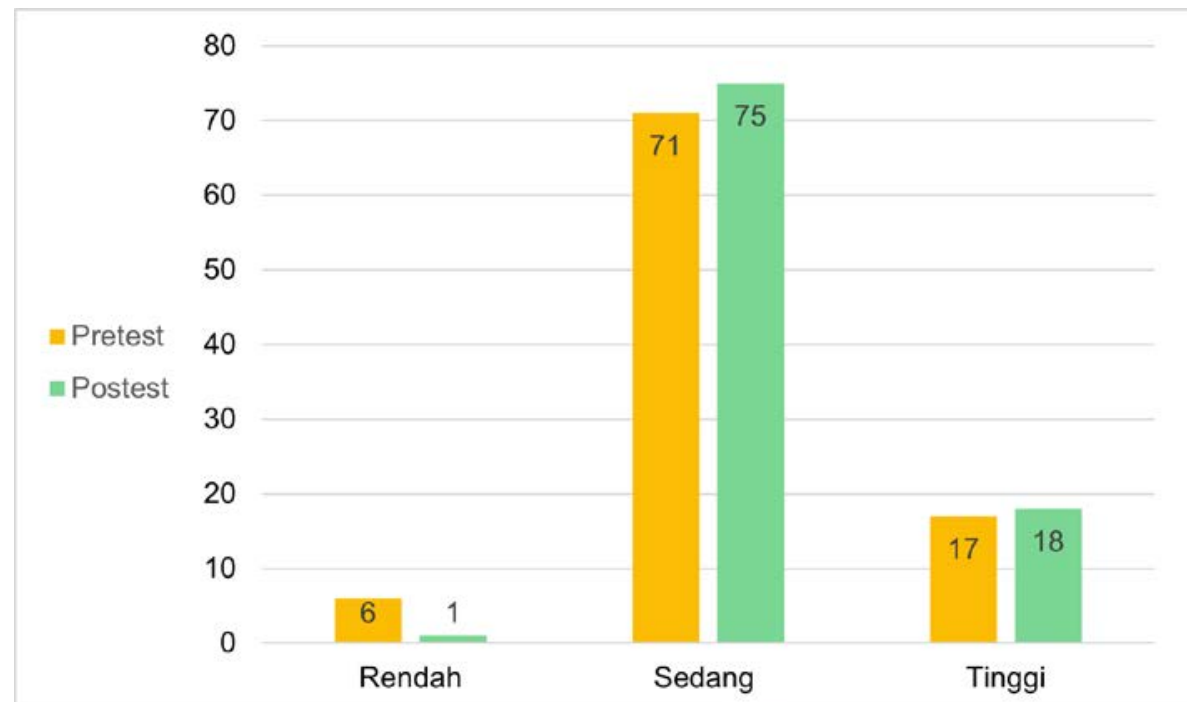

Gambar 3. Interpretasi nilai pre-test dan post-test persepsi guru terhadap pendekatan Gamification

Hasil pre-test dan post-test yang telah disampaikan di atas dianalisis lebih lanjut dengan menggunakan uji statistik. Uji-t berpasangan digunakan untuk melihat perbedaan yang signifikan 
antara hasil yang diperoleh dari kedua tes tersebut. Berdasarkan hasil uji-t berpasangan didapatkan hasil bahwa perbedaan skor yang antara pre-test dan post-test secara signifikan berbeda nyata yang ditunjukkan dengan nilai signifikansi ( $\mathrm{p}$-value) sebesar $0,037<\alpha(0,05)$.

Tabel 2. Hasil Uji-t berpasangan skor pre-test dan post-test.

Paired Differences

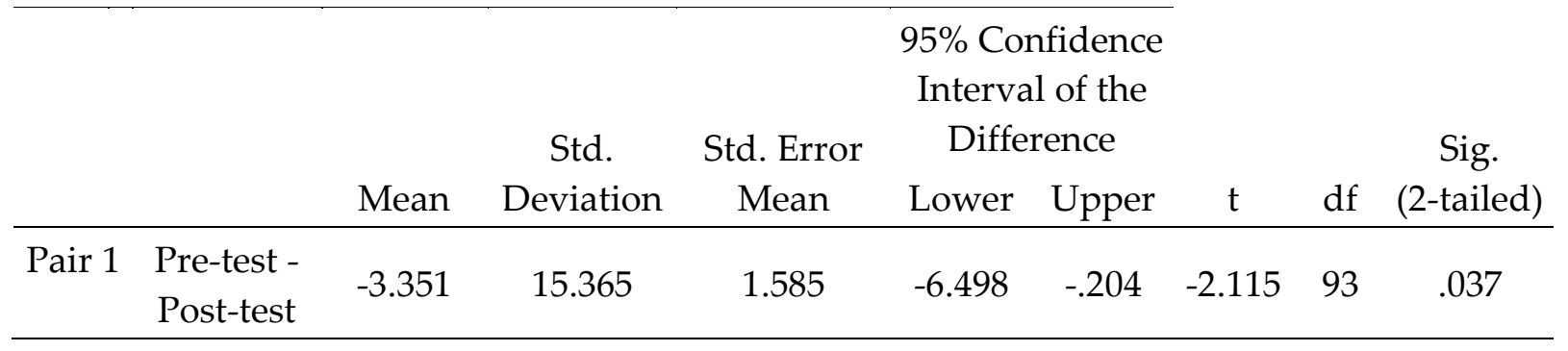

Perubahan persepsi ini diharapkan dapat memberikan pengaruh yang baik pula dalam penggunaan teknologi menggunakan pendekatan Gamification ini di dalam kelas. Seperti pendapat yang dikemukakan Gorder bahwa keefektifan pengimplementasian teknologi dipengaruhi oleh banyak faktor dan salah satu factor pentingnya adalah kompetensi dan kemampuan guru dalam mendesain pembelajaran berbasis teknologi yang sesuai dengan kebutuhan siswa (Gorder, 2008).

Pembelajaran dalam era digital saat ini memiliki tantangan yang besar salah satunya adalah adaptasi guru mengenai penggunaan teknologi. Teknologi dan Pendidikan merupakan dua hal yang saling berkait dan berhubungan erat, jika guru tidak menggunakan teknologi dalam proses pembelajaran terutama maka dapat dipastikan bahwa guru telah memutus hubungan antara proses belajar siswa di sekolah dengan proses belajar mereka dalam kehidupan sehari-hari diluar sekolah (Mundy et al., 2012). Terutama di era digital saat ini dan dalam situasi pandemi covid 19 yang sedang melanda seluruh dunia sehingga proses pembelajaran harus berlangsung secara daring. Menurut Mundy dalam hasil penelitiannya menyatakan bahwa guru setuju bahwa teknologi membuat Pendidikan menjadi lebih efektif. Sebagian besar dari mereka setuju bahwa teknologi dapat meningkatkan pencapaian siswa dan juga memberikan pengalaman belajar sepanjang haya (lifelong learning) (Mundy et al., 2012).

Gamification sendiri merupakan pendekatan dalam proses pembelajaran yang sudah ada sejak lama (Piet van den Boer, n.d.). Akan tetapi penggunaannya dalam proses belajar di negaranegara berkembang seperti Indonesia masih belum terlalu banyak dilakukan. Padahal Gamification telah banyak diteliti dan dipercaya dapat meningkatkan motivasi serta keterikatan siswa dalam proses pembelajaran (Barata et al., 2013; Da Rocha Seixas et al., 2016; Hanus, M. D. \& Fox, 2015). Beberapa pendapat yang pernah diberikan dari hasil penelitian menyatakan bahwa jika seorang guru tidak memiliki kepercayaan bahwa teknologi dapat membantu mereka dalam melaksanakan kegiatan pembelajaran maka cukup beralasan jika mereka menolak untuk mau beradaptasi terhadap penggunaan teknologi (Teo et al., 2016). Oleh karena itu, diperlukan pengenalan, sosialisasi dan pelatihan secara komprehensif dan berkelanjutan dalam rangka meningkatkan kepercayaan dan persepsi guru untuk mau menggunakan teknologi dalam proses belajarnya.

Terdapat beberapa faktor yang menyebabkan guru enggan melakukan proses adaptasi teknologi khususnya pada penggunaan game digital dan Gamification yakni (i)factor dari dalam diri guru itu sendiri seperti pengalaman, kepercayaan, sikap, dan keterampilan dasar penggunaan teknologi; (ii) hal-hal yang berkaitan dengan system seperti terkesan tidak seperti belajar tapi bermain-main, ketepatan tantangan, keterkaitan dengan kurikulum, dan peluang belajar; (iii) keterkaitan aspek dari konten yang dipelajari seperti budaya, ketersediaan sarana dan prasarana serta kesiapan siswa (Bourgonjon et al., 2013; De Grove et al., 2012; Hamari \& Nousiainen, 2015; 
Hanus \& Fox, 2015; Li \& Huang, 2016; Teo et al., 2016). Hal ini sehalan dengan penelitian Antonio dengan four main drivers (attention-motivation, entertainment, interactivity, and easiness to learn) dan four barriers (lack of resources, students' apathy, subject fit, and classroom dynamics) yang merupakan hal-hal yang mempengaruhi penggunaan Gamification dalam kelas dari sudut pandang guru (Sánchez-Mena \& Martí-Parreño, 2017). Asta dalam penelitiannya berpendapat bahwa usaha membangun kepercayaan dan persepsi guru terhadap kesan bermain, kesesuaian dengan kurikulum memberikan pengaruh terhadap intensitas dari usaha mereka untuk mau mengubah perilaku dan beradaptasi terhadap penggunaan Gamification (Adukaite et al., 2017).

Selain dari hal-hal diatas, penggunaan istilah dalam Bahasa inggris yang mungkin terdengar sangat canggih dan rumit juga membuat guru enggan mengenal lebih jauh mengenai Gamification. Walaupun pada kenyataannya Gamification hanya sebuah pendekatan yang juga dapat dilakukan dengan media dan metode yang sangat sederhana. Kecenderungan pemikiran yang demikian dapat membuat seseorang menjadi enggan mencoba dan mengenal lebih jauh mengenai hal yang baru tersebut. Oleh karena itu, kegiatan seperti pelatihan, seminar, sharing dan workshop sangat perlu dilakukan dalam rangka mengsosialisasikan mengenai hal yang baru tersebut sehingga paling tidak persepsi negatif dari pengguna (guru) menjadi berkurang. Dengan berkurangnya persepsi negatif tersebut diharapkan kemudian guru mau untuk mulai mengenal lebih jauh, mempelajari dan kemudian mencoba untuk mempraktekannya di dalam desain pembelajaran mereka masing-masing di dalam kelas.

\section{KESIMPULAN}

Berdasarkan hasil data yang diperoleh, persepsi responden terhadap penggunaan pendekatan Gamification mengalami perubahan persepsi dalam proses pembelajaran. Berdasarkan hasil pre-test dan post-test yang dilakukan terlihat bahwa terjadi peningkatan persepsi ke arah yang lebih positif dari guru IPA mengenai penggunaan pendekatan Gamification ini.

\section{UCAPAN TERIMA KASIH}

Terima kasih penulis ucapkan kepada POK BLU FMIPA, Universitas Negeri Jakarta sebagai pemberi dana untuk berlangsungnya kegiatan ini. Guru-guru IPA SD dari mitra (YPI AL Azhar) dan seluruh guru yang hadir sebagai peserta. Prenadamedia dan Rajagrasindo yang telah bersedia menjadi sponsor dalam kegiatan.

\section{DAFTAR PUSTAKA}

Achmat, Z. (2005). Efektifitas Pelatihan Pengembangan Kepribadian dan Kepemimpinan dalam Meningkatkan Kepercayaan Diri Mahasiswa Baru UMM Tahun 2005/2006.

Adukaite, A., van Zyl, I., Er, Ş., \& Cantoni, L. (2017). Teacher perceptions on the use of digital gamified learning in tourism education: The case of South African secondary schools. Computers and Education, 111, 172-190. https://doi.org/10.1016/j.compedu.2017.04.008

Alabbasi, D. (2017). Exploring graduate students' perspectives towards using gamification techniques in online learning. Turkish Online Journal of Distance Education, 18(3), 180-196. https://doi.org/10.17718/tojde.328951

Barata, G., Gama, S., Jorge, J., \& Gonçalves, D. (2013). Improving participation and learning with gamification. ACM International Conference Proceeding Series, 10-17. https://doi.org/10.1145/2583008.2583010

Bourgonjon, J., De Grove, F., De Smet, C., Van Looy, J., Soetaert, R., \& Valcke, M. (2013). Acceptance of game-based learning by secondary school teachers. Computers and Education, 67, 21-35. 
https://doi.org/10.1016/j.compedu.2013.02.010

Da Rocha Seixas, L., Gomes, A. S., \& De Melo Filho, I. J. (2016). Effectiveness of gamification in the engagement of students. Computers in Human Behavior, 58, 48-63. https://doi.org/10.1016/j.chb.2015.11.021

De Grove, F., Bourgonjon, J., \& Van Looy, J. (2012). Digital games in the classroom? A contextual approach to teachers' adoption intention of digital games in formal education. Computers in Human Behavior, 28(6), 2023-2033. https://doi.org/10.1016/j.chb.2012.05.021

Deterding, S., Dixon, D., Khaled, R., A., \& Nacke, L. (2011). From game design elements to gamefulness: defining gamification. Proceedings of the 15th International Academic MindTrek Conference: Envisioning Future Media Environments, 9-15.

Fowlie, J. (2000). Emotional Intelligence: The Role of Self-Confidence in Preparing Business School Undergraduates for Placement/Employment. [Internet]. http://www.herts.ac.uk

Gorder, L. M. (2008). A Study of Teacher Perceptions of Instructional Technology Integration in the Classroom. Delta Pi Epsilon, 2, 63-76.

Greenway, R. (2005). Experiential Learning Cycles.

Hamari, J., \& Nousiainen, T. (2015). Why do teachers use game-based learning technologies? The role of individual and institutional ICT readiness. Proceedings of the Annual Hawaii International Conference on System Sciences, 2015-March, 682-691. https://doi.org/10.1109/HICSS.2015.88

Hanus, M. D., A., \& Fox, J. (2015). Assessing the effects of gamification in the classroom: A longitudinal study on intrinsic motivation, social comparison, satisfaction, effort, and academic performance. Computers \& Education, 80, 152-161.

Li, S. C. S., \& Huang, W. C. (2016). Lifestyles, innovation attributes, and teachers' adoption of game-based learning: Comparing non-adopters with early adopters, adopters and likely adopters in Taiwan. Computers and Education, 96, 29-41. https://doi.org/10.1016/j.compedu.2016.02.009

Mundy, M. A., Kupczynski, L., \& Kee, R. (2012). Teacher's perceptions of technology use in the schools. SAGE Open, 2(1), 1-8. https://doi.org/10.1177/2158244012440813

Piet van den Boer. (n.d.). Introduction.

Sánchez-Mena, A., \& Martí-Parreño, J. (2017). Drivers and barriers to adopting gamification: Teachers' perspectives. Electronic Journal of E-Learning, 15(5), 434-443.

Teo, T., Milutinović, V., \& Zhou, M. (2016). Modelling Serbian pre-service teachers' attitudes towards computer use: A SEM and MIMIC approach. Computers and Education, 94, 77-88. https://doi.org/10.1016/j.compedu.2015.10.022 